\title{
Test Writers' Perceptions of English Language Tests in Relation to the Common European Framework of Reference (CEFR) at a Saudi Arabian University
}

\author{
Gamal Shehata "PhD Candidate" (Corresponding Author) \\ English Language Instructor \& Head of Curriculum, Testing \& E-Learning Unit, ELC, Taibah \\ University, Airport Road, P.O. Box 52958, Madina 41573, KSA
}

\section{Professor Ayub Sheik}

Professor of English Education, Corner of Richmond and Marianhill Road, Edgewood Campus, University of KwaZulu-Natal, South Africa, Private Bag X03. Ashwood, 3605

Received: July 25, 2020 Accepted: August 20, 2020 Published: August 24, 2020

doi:10.5296/ijele.v8i2.17578 URL: https://doi.org/10.5296/ijele.v8i2.17578

\begin{abstract}
The CEFR is currently being used globally as a guiding document for specifying the standards of language learning, teaching, and assessment. The university wherein this study takes place, assumes that its internally produced English language tests are CEFR-related because they are based on textbooks which claim affinity with the CEFR. This study investigates the validity of this assumption. The literature review suggests a wealth of studies which link a specific test or exam to the CEFR based on the technical procedures laid out in the Manual for Relating Language Examinations to the CEFR (the Manual). This study has a different approach as it investigates whether the internally produced English language tests at a Saudi Arabian university are linked/related to the CEFR from the perspectives of the academic staff who are responsible for producing the English language tests at the university wherein this study is conducted. As such, this study is situated within an interpretative case study paradigm and uses a mixed method methodology for data collection and analysis. The study showed that all the research participants share the view that the English language exams which they develop are CEFR linked/related because they are based on the learning outcomes of textbooks which, according to the publisher, are CEFR linked. In addition, the contextual issues related to the implementation of the Manual and the CEFR are to be considered. The study presents implications and recommendations for the institution and for ELT publishers who claim that their ELT materials are CEFR linked.
\end{abstract}


Keywords: Common European Framework of Reference (CEFR), Relating Language Examinations to the CEFR, English Language Teaching (ELT), Learning Management System (LMS) and Test Writers

\section{Introduction}

The Common European Framework of Reference for Languages (CEFR) was officially launched by the Council of Europe in 2001. It was conceived as a groundbreaking language policy document as it "provides a common basis for the elaboration of language syllabuses, curriculum guidelines, examinations, textbooks, etc. across Europe" (Council of Europe, 2001, p. 1). Moreover, the CEFR has been recognized as "the most significant recent event on the language education scene in Europe" (Alderson, 2005, as cited in Kntarcioglu and Papageorgiou, 2012, p. 82). One of the main purposes of the CEFR is the alignment of language learning, teaching, assessment and testing to ultimately ensure comparability of learning outcomes across languages, contexts, and countries. Therefore, research indicates that the CEFR is specifically concerned with testing and examinations (Coste, 2007; Kntarcioglu and Papageorgiou, 2012; Martyniuk, 2010). For instance, according to Coste (2007), one of the authors of the CEFR, the CEFR's influence on language assessment has been particularly noteworthy, and the process involved in aligning language tests to the CEFR's Common Reference Levels has received more attention than any other aspect of the Framework (Council of Europe, 2011). Kntarcioglu and Papageorgiou (2012) agree with this view as they contend that the impact of the CEFR on language examinations and tests "...has been widespread as the majority of language examination providers claim that their test scores relate to the CEFR levels" (Kntarcioglu and Papageorgiou, 2012, p. 82).

In addition, related literature indicates that since its inception, the influence of the CEFR has crossed the boarders of Europe and the document has been incorporated in the foreign language education systems and is now used, adapted, consulted, or studied in a variety of countries worldwide (Byram \& Parmenter, 2012 and Nagai \& O’Dweyer, 2011). However, the CEFR related literature outlines some of the criticism of the CEFR. For instance, Figueras (2012) indicates that the CEFR is not a model of absolute perfection, and involves criticisms and challenges. One major criticism of the CEFR is related to its accessibility and that it is not user-friendly, and it is difficult to understand. Other points of criticism are attributed to the CEFR's Common Reference Levels and their illustrative descriptors (Can-Do Statements) and the CEFR's role in curriculum design, learning, teaching, and assessment. Other criticisms are related to the alignment of language examinations and tests to the CEFR.

\subsection{Background to the Study}

This study is conducted in the Unified Science Track Program (USTRP) (formerly named as the Preparatory Year Program), at the English Language Center of a public university in the Kingdom of Saudi Arabia (KSA). All students who join this program were in the science stream in high school and successfully passed high school and met the entry requirements of the university addressed in this study. However, the university requires that these science 
track students take a one-year-program of study before they are permitted to join the various scientific colleges of the university (e.g. Medicine, Pharmacy, Health Sciences colleges, Computer Sciences, Engineering, etc.). Humanities students are not included in this program as they are allowed to join the humanities colleges without studying a preparatory year. The USTP is established to prepare students for the academic demands of undergraduate studies at the university. The USTP includes two English language courses which are conducted over two semesters. These two English courses are named ENG101 and ENG102. The ENG101 course is offered in the first semester and is a pre-requisite for ENG102, which is offered in the second semester. The ENG102 course is also offered in the summer semester for students who do not pass the ENG102 course in the second semester.

Moreover, the ENG102 course is offered in the first semester of the new academic year for those students who do not manage to pass it in the summer semester. For both ENG101 and ENG102, the Middle East version of Q: Skills for Success series (2nd edition) is used as a syllabus. This series is designed by Oxford University Press (OUP) and comprises five language levels; however, the two English courses i.e. ENG101 \& ENG102 which the students have to study include Q: Skills 1, Q: Skills 2 and Q: Skills 3. Each level consists of two strands of language development in the domains of Listening / Speaking \& Reading / Writing and are thematically related. Each strand includes 8 units. The Q:Skills series is supported by an electronic program called ' $\mathrm{i}-$ Tools' that is installed on every teacher's laptop and is used to present the course material, inclusive of the audio-visual materials. The Q: Skills series is also supported by an online Learning Management System (LMS) called 'iQ Online', which includes a wide range of interactive practice activities and online tests. According to OUP, these levels are benchmarked to the CEFR's language levels A1, A2, \& B1 (Table 1).

Table 1. Q: Skills books correlation to the CEFR levels (By Oxford University Press)

\begin{tabular}{|c|c|c|}
\hline Q: Skills Books & Level & CEFR Language Level \\
\hline $\begin{array}{c}\text { Q: Skills Level 1 } \\
\text { (Listening / Speaking \& Reading / Writing) }\end{array}$ & 1 & A1 (Breakthrough) \\
\hline $\begin{array}{c}\text { Q: Skills Level 2 } \\
\text { (Listening / Speaking \& Reading / Writing) }\end{array}$ & 2 & A2 (Waystage) \\
\hline $\begin{array}{c}\text { Q: Skills Level 3 } \\
\text { (Listening / Speaking \& Reading / Writing) }\end{array}$ & 3 & B1 (Threshold) \\
\hline
\end{tabular}

Mapping of Q: Skills books to the CEFR (by Oxford University Press, 2020)

English language teaching institutions in the Arab world and the Middle East use textbooks that their publishers claim that they are CEFR-linked in order to:

a. ensure the quality of the ELT materials that are used in the English language program;

b. align the learning outcomes of the English language program to international standards (such as the CEFR English language proficiency levels); 


\section{$\triangle$ Macrothink}

c. give credibility and robustness to the English language program; and

d. check whether students have achieved the target CEFR proficiency level (i.e. B1) upon exiting the preparatory English language program at the institution addressed in this study.

The teaching of English in the context of this study is conducted in classroom which are fully equipped with the most up-to-date educational technology e.g. interactive whiteboards, multimedia data shows, Internet, etc. Moreover, the university provided all English language teachers with laptops to enhance the teaching process. On the other hand, the assessment plan of both the ENG 101 and ENG102 courses includes a variety of assessments such as a writing portfolio, 2 speaking tests, a writing test, online tests, midterm and final tests. The writing portfolio, writing test, and speaking tests are subjective and formative in nature. However, the online tests, midterm and final tests are objective in nature, and they are all in the form of Multiple-Choice Questions (MCQs). Moreover, the midterm and final tests are computer-based and are conducted on campus, and they are summative in nature. It is also worth noting that students may access and complete the LMS online practice tests from anywhere provided that they have Internet connection, however these LMS tests have deadlines which students have to meet. Table 2 below illustrates the distribution and weighting of all the assessments in each of the two courses. All assessments are centrally designed and produced by the internal test writers who work in the testing unit of the English language center of the university. All the assessments are standardized, meaning that all students in the USTP take the same assessments at the same time across all the 10 campuses of the university. It is also worth noting that all assessments are based on the content and unit learning outcomes of the Q: Skills textbooks, levels 1, 2, \& 3. These learning outcomes are specified by the textbook publisher and are stated in both the contents' page and inside each unit of the textbook. Therefore, the university under discussion assumes that its English internal tests are CEFR linked / related, because they are based on the publisher's claims of being CEFR linked/related.

Table 2. Assessment plan of the English language program (ENG 101 \& ENG102)

\begin{tabular}{|c|c|c|c|c|c|}
\hline \multicolumn{2}{|c|}{ ENG101 } & \multicolumn{3}{c|}{ ENG102 } \\
Component & Weight & $\begin{array}{c}\text { Time } \\
\text { Duration }\end{array}$ & $\begin{array}{c}\text { Assessment } \\
\text { Component }\end{array}$ & Weight & Time Duration \\
\hline Writing Portfolio & $5 \%$ & $\begin{array}{c}\text { Over the } \\
\text { academic } \\
\text { semester }\end{array}$ & Writing Portfolio & $5 \%$ & $\begin{array}{c}\text { Over the } \\
\text { academic } \\
\text { semester }\end{array}$ \\
\hline Speaking Test (1) & $5 \%$ & $\begin{array}{c}6 \text { minutes per } \\
\text { student }\end{array}$ & Speaking Test (1) & $5 \%$ & $\begin{array}{c}6 \text { minutes per } \\
\text { student }\end{array}$ \\
\hline Speaking Test (2) & $5 \%$ & $\begin{array}{c}6 \text { minutes per } \\
\text { student }\end{array}$ & Speaking Test (2) & $5 \%$ & $\begin{array}{c}6 \text { minutes per } \\
\text { student }\end{array}$ \\
\hline Writing Test & $5 \%$ & 60 minutes & Writing Test & $5 \%$ & 60 minutes \\
\hline
\end{tabular}




\begin{tabular}{|c|c|c|c|c|c|}
\hline $\begin{array}{c}\text { Online Practice } \\
\text { Test (Listening \& } \\
\text { Speaking Strand) }\end{array}$ & $2.5 \%$ & $\begin{array}{c}\text { Weekly over } \\
\text { the academic } \\
\text { semester }\end{array}$ & $\begin{array}{c}\text { Online Practice } \\
\text { Test (Listening \& } \\
\text { Speaking Strand) }\end{array}$ & $2.5 \%$ & $\begin{array}{c}\text { Weekly over the } \\
\text { academic } \\
\text { semester }\end{array}$ \\
\hline $\begin{array}{c}\text { Online Practice } \\
\text { Test (Reading \& } \\
\text { Writing Strand) }\end{array}$ & $2.5 \%$ & $\begin{array}{c}\text { Weekly over } \\
\text { the academic } \\
\text { semester }\end{array}$ & $\begin{array}{c}\text { Online Practice } \\
\text { Test (Reading \& } \\
\text { Writing Strand) }\end{array}$ & $2.5 \%$ & $\begin{array}{c}\text { Weekly over the } \\
\text { academic } \\
\text { semester }\end{array}$ \\
\hline $\begin{array}{c}\text { Midterm Test } \\
\text { (Computer-based) }\end{array}$ & $35 \%$ & 100 minutes & $\begin{array}{c}\text { Midterm Test } \\
\text { (Computer-based) }\end{array}$ & $35 \%$ & 100 minutes \\
\hline $\begin{array}{c}\text { Final Test } \\
\text { (Computer-based) }\end{array}$ & $40 \%$ & 100 minutes & $\begin{array}{c}\text { Final Test } \\
\text { (Computer-based) }\end{array}$ & $40 \%$ & 100 minutes \\
\hline Total: & $\mathbf{1 0 0 \%}$ & & Total: & $\mathbf{1 0 0 \%}$ & \\
\hline
\end{tabular}

Overall assessment Plan of the English Language of the USTP

\subsection{Statement of the Problem}

As stated in the earlier section of this paper, the institution addressed in this study uses three English language textbooks of the Q:Skills series in the teaching of English in its Unified Science Track Program (USTP), which is a preparatory English language program. These textbooks are Q:Skills 1, Q:Skills 2, and Q:Skills 3. The publisher of this series, OUP, claims that these books are linked to the CEFR English levels A1, A2, and B1.

In addition, the internal English language tests of the USTP are based on the learning outcomes of these specific textbooks. The university under discussion, therefore, assumes that its internally produced tests are CEFR linked because they are based on textbooks which the publisher claims are CEFR linked/related.

This study, therefore, seeks to investigate whether the internal English language tests at the university wherein this study is conducted are linked and/or related to the CEFR from the perspectives of the academic staff members (i.e. the test writers) who are responsible for producing the English tests in the context addressed in this study.

\subsection{Questions of the Study}

The study is based on the following research questions:

1. Do the test writers, in the context addressed in this study, perceive that the internal English language tests are CEFR linked/related?

1.1 Why, or why not?

\section{Literature Review}

According to the Council of Europe (2001), one of the aims of the CEFR is to help its users 
to describe the levels of proficiency as required by existing standards, tests, and examinations in order to facilitate comparisons between different systems of qualifications. For this purpose, the Descriptive Scheme and the Common Reference Levels have been developed. Therefore, within a relatively short period of time, the CEFR has become highly influential in Europe and beyond as a way of formulating objectives for language learning and teaching (Council of Europe, 2018). In addition, the related literature indicates that with the recent growing interest in the CEFR, the number of institutions linking their examinations to the CEFR has also increased. This is demonstrated in publications by Figueras and Nijons (2009) and Martyniuk (2010). For instance, Martyniuk (2010) denotes that there is a growing interest worldwide in establishing comparability between assessment standards, whether these are technical relating to matters of quality assurance or descriptions of performance levels that offer benchmarks for comparison. He points out that these standards "....tend to be influential since they provide policy makers with tools that can be used for gathering baseline data, for benchmarking and for evaluating current practices" (Martyniuk, 2010, p. viii).

On the other hand, some language testing figures (e.g. Weir, 2005-2010, Taylor, 2004, McNamara, 2007, 2006 and 2001) draw the attention to some of the limitations in using the CEFR in developing comparable exams. For instance, McNamara (2000) argues against using rating scales such as those presented in the CEFR's Common Reference Levels and their Can-Do descriptors. He asserts that most rating scales do not have a single point of reference which allows the discriminations in the rating of a performance to be made around such a point of reference. Moreover, Weir (2005) argues that "in its present form, the CEFR is not sufficiently comprehensive, coherent or transparent for uncritical use in language testing" (Weir, 2005, p. 281). He indicates that, currently, the CEFR “...exhibits a number of serious limitations such that comparisons based entirely on the scales alone might prove to be misleading, given the insufficient attention paid in these scales to issues of validity" (Weir, 2005, p. 281d). Furthermore, CEFR related literature shows that a few studies argue that the CEFR is produced by and designed to suit European contexts, and it is not applicable to education contexts beyond Europe. For instance, McBeath (2011) denotes that within Europe, the CEFR offers a win-win scenario; however, he questions whether this European scenario has any relevance to countries outside the members of the Council of Europe. He points out that "There is no reason why it should, unless countries beyond Europe intend to tie their educational qualifications into the CEFR system" (McBeath, 2011, p. 208). Nonetheless, it is worth pointing out that since its early development (Between 1993\&1996) until its final publication in 2001, the CEFR and its related publications (from 2001-2018) have always stressed the importance of the context in which it is implemented. For instance, Martyniuk (2010) indicates that the CEFR is useful as a common framework, however "... it is not applicable to all contexts without user intervention in order to adapt it flexibly to suit local purposes" (Martyniuk, 2010, p. xa). He argues that the CEFR is context neutral, therefore it needs to be applied and interpreted in light of the specific needs in which it is used and implemented.

\subsection{What does linking/relating a test to the CEFR mean?}


Aligning or linking a language test/examination to the CEFR refers to the existence of a relationship between the test/examination and the CEFR. According to the Manual, the existence of such a relationship is not a simple observable fact, but it “...is an assertion for which the examination provider needs to provide both theoretical and empirical evidence (Council of Europe, 2009, p. 7). This implies that language education institutions and examination bodies that claim/assume that their language examination(s) is (are) related to the CEFR have to provide a research-based evidence to justify these claims/assumptions.

\subsection{What Has the CEFR Offered to Assist Institutions/Examination Bodies to Align their Tests and Examinations to the CEFR?}

In response to perceptions and expectations that the CEFR could and should offer a set of stable and acceptable standards for testing and assessment purposes, the Council of Europe provided a toolkit of resources to inform and facilitate the process of aligning and linking tests to the CEFR. The toolkit included a draft pilot Manual for Relating Language Examinations to the CEFR in 2003, followed by a technical reference supplement to the Manual during 2003 and 2004, with a later revised version of the Manual in 2009.

Later in 2009, the Council of Europe had also produced a publication titled 'Relating Language Examinations to the Common European Framework of Reference for Languages: Learning, teaching, assessment (CEFR): Highlights from the Manual'. This publication was the result of a project of the European Centre for Modern Languages titled "Training in Relating Examinations to the Common European Framework of Reference for Languages" (Council of Europe, 2009). These highlights from the Manual were aimed at policy makers, assessment experts at examination centers, curriculum developers, teacher trainers, and other educationalists less familiar with the technicalities of the linking process.

Moreover, the Council of Europe provided forums where practitioners could share their reflections on the draft manual and their experiences in using the different linking stages as suggested within it. Examples of such forums included a seminar entitled 'Reflections on the Use of the Draft Manual for Relating Language Examinations to the CEFR: Insights from Case Studies' held in Cambridge in December 2007. The insights from this colloquium informed the Manual revision project during 2008 and 2009.

\subsection{The Manual for Relating Language Examinations to the CEFR (The Manual)}

According to the Manual, the process of linking a test to the CEFR consists of a set of procedures that need to be carried out at different stages: Familiarization, Specification, Standardization training/benchmarking, Standard setting, and Validation. Figure 1 below is a visual representation of the stages in the process of relating examinations to the CEFR. It highlights how linking an examination or a test may be seen as the development of a line of argument, making claims about different aspects of linkage, and providing corroborating evidence of their validity as the process unfolds. Whereas the Manual (Council of Europe, 
2009) indicates that not all examination providers can undertake studies in all the areas outlined in the Manual, it points out that even less well-resourced examination providers should select the techniques from all areas. It argues that a claim that a qualification is linked to the CEFR can only be taken seriously if evidence exists that claims based on specifications (content standards) and standard setting (performance standards) are corroborated through validation (Council of Europe, 2009).

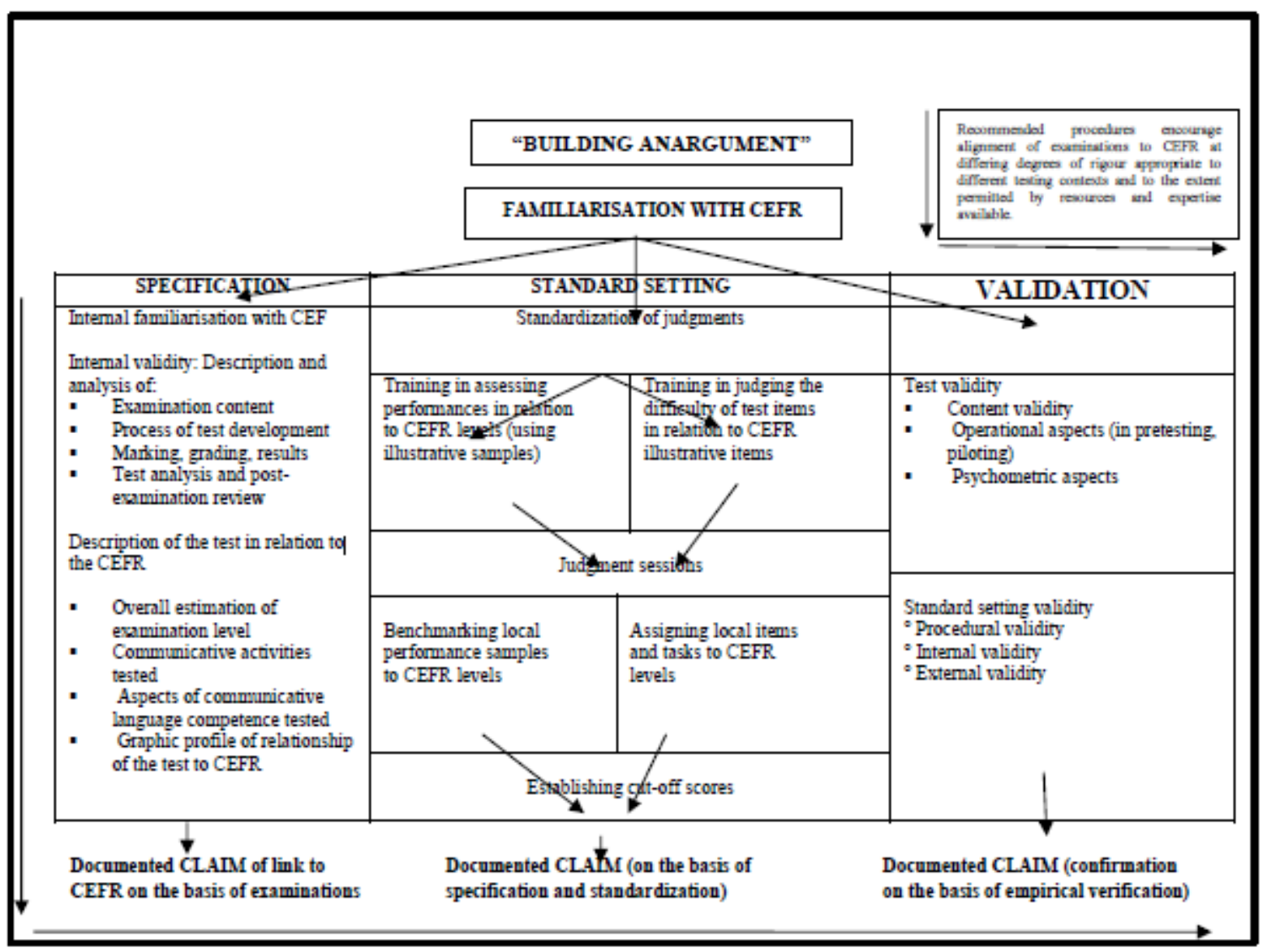

Figure 1: Visual Representation of Procedures to Relate Examinations to the CEFR (Council of Europe, 2009, p. 15)

\section{The Theoretical Approach}

To address the main question of the study, the researcher used quantitative and qualitative instruments for data collection and analysis. It is believed that combining quantitative and qualitative research methodology adds rigor to the present study in terms of the validity and reliability of the research findings (Bryman, 2006). The quantitative aspect of the research involved the use of a pre-designed survey questionnaire (Phase One). The pre-designed survey questionnaires are followed by a qualitative aspect i.e. one-to-one semi-structured interviews (SSIs) (Phase Two) in order to get a more in-depth understanding of the 
participants' responses and give meaning to the quantitative data. Therefore, the semi-structured interviews stand as the main source of data collection in this study. A detailed discussion of the use of the research tools is presented in the methodology section of this study.

\section{Methodology}

\subsection{Research Participants}

The size and the selection of the research sample were in line with the focus and the main question of the current research paper. In other words, the study involved all the test writers (i.e. 4 test writers) in the context addressed in this study. All test writers are expatriates between the ages of thirty-eight and fifty-seven who have been teaching English in the context under discussion for more than nine years. However, their actual work experience in writing and producing the English tests at the research site ranges between two and half years to nine years. One test writer is from South Africa, the second is from the United Kingdom, the third is from Syria, and the fourth is from Egypt.

\subsection{Research Instruments}

\subsubsection{Pre-designed -Self-Administered Questionnaire}

The pre-designed questionnaire for the test writers (Appendix A) included 7 items or statements that are related to the topic of the current study, as well as the research questions which this study seeks to answer. The questionnaire adopted an ordinal rating scale, i.e. 'strongly disagree' to 'strongly agree' in order to elicit responses from the participants.

\subsubsection{Semi Structured One-to-One Interviews}

The second and main source of data used as evidence in this study comes from one-to-one semi-structured interviews. The interviews involved the same participants who were given the pre-designed survey questionnaire (i.e. The 4 test writers). A schedule of the interviews has been developed based on the time available for each participant. The SSIs are structured around the responses obtained in the survey questionnaire which each participant has completed. In other words, the responses given by each participant in the completed survey questionnaire were used as prompts and probes to confirm or verify the data obtained from the pre-designed questionnaires and gain a more in-depth understanding of the responses from the research participants. Therefore, the semi-structured interviews are the main source of data collection.

\subsubsection{Procedures}

To answer the main question of the study, the researcher applied the following procedures:

a) Reviewed the literature related to relating / linking language examinations to the CEFR. 
b) Developed a pre-designed survey questionnaire to elicit responses from the target research sample (i.e. the Test Writers).

c) Piloted the pre-designed survey questionnaire on a small sample (one Test Writer) of the target research sample. This individual was not included in the final sample population surveyed.

d) Self-administered the pre-designed survey questionnaire and elicited responses from the sample population.

e) Conducted and recorded the one-to-one semi structured interviews.

f) Transcribed the SSIs using NVIVO Transcription software to prevent any loss of data.

g) Coded and analyzed the results.

h) Discussed the obtained results.

i) Presented recommendations and suggestions for further studies.

\subsubsection{Limitations of the Study}

One limitation of this study is that it did not involve the policy makers regarding the same phenomenon which it investigates. Policy makers and higher administration staff members play key roles in the decision-making process with regards to learning, teaching, and assessment of the learners in the context addressed in this study. Therefore, their views and perceptions about the phenomenon addressed in this study are likely to be important as well. Another limitation of this study is related to the generalization of the results. Therefore, any future research studies on the same phenomenon of this study would need to acknowledge the similarities and differences between this research and their research in terms of the context, background, and setting of this study.

\section{Findings}

\subsection{Quantitative Findings}

As indicated in earlier sections of this study, four test writers completed the pre-designed questionnaire. Table 3 shows the responses of the 4 test writers to each of the statements of the pre-designed questionnaire (i.e. from number 1 to number 7). The name of the institution addressed in this study is removed in order to assure anonymity and confidentiality of the institution. This was done by substituting the name of the institution with the letter $\mathrm{T}$ between block brackets as shown in this example: [T]. Also, each Test Writer is given a code (i.e. TW1, TW2, TW3 and TW4). Table 3 below shows the quantitative results of the Test Writers' responses to each statement of the pre-designed survey questionnaire.

Table 3. Quantitative analysis and results of test writers' responses to the questionnaire statements 


\section{Macrothink}

\begin{tabular}{|c|c|c|c|c|c|c|c|c|}
\hline $\begin{array}{c}\text { Statement } \\
\#\end{array}$ & \multicolumn{4}{|c|}{ Rating Scale } & \multicolumn{3}{c|}{$\begin{array}{c}\text { Breakdown of \% by } \\
\text { Participants }\end{array}$} \\
\cline { 2 - 10 } & $\begin{array}{c}\text { \% } \\
\text { Strongly } \\
\text { Disagree (SD) } \\
\end{array}$ & $\begin{array}{c}\text { \% } \\
\text { Disagree } \\
\text { (D) }\end{array}$ & $\begin{array}{c}\text { Agree } \\
\text { (A) }\end{array}$ & $\begin{array}{c}\text { \% } \\
\text { Strongly } \\
\text { Agree } \\
\text { (SA) }\end{array}$ & TW1 & TW 2 & TW3 & TW4 \\
\hline S1 & $0,00 \%$ & $0,00 \%$ & $75,00 \%$ & $25,00 \%$ & A & SA & A & A \\
\hline S2 & $0,00 \%$ & $0,00 \%$ & $0,00 \%$ & $100,00 \%$ & SA & SA & SA & SA \\
\hline S3 & $0,00 \%$ & $0,00 \%$ & $50,00 \%$ & $50,00 \%$ & SA & SA & A & A \\
\hline S4 & $0,00 \%$ & $50,00 \%$ & $0,00 \%$ & $50,00 \%$ & D & SA & D & SA \\
\hline S5 & $0,00 \%$ & $50,00 \%$ & $25,00 \%$ & $25,00 \%$ & D & SA & D & A \\
\hline S6 & $25,00 \%$ & $50,00 \%$ & $25,00 \%$ & $0,00 \%$ & SD & D & D & A \\
\hline S7 & $0,00 \%$ & $25,00 \%$ & $50,00 \%$ & $25,00 \%$ & SA & A & D & A \\
\hline
\end{tabular}

\subsection{Descriptive Statistics}

Table 3 above shows the following results:

a) As illustrated in Figure 2, 75\% of the participants (TW1, TW3 and TW4) agreed that 'The textbooks which are used at [T] are linked / related to the CEFR', while $25 \%$ of the test writer participants (i.e. TW2) strongly agreed with this statement.

Statement 1: 'The textbooks which are used in the teaching of English at [T] are linked/related to the CEFRs'trongly Disagree,

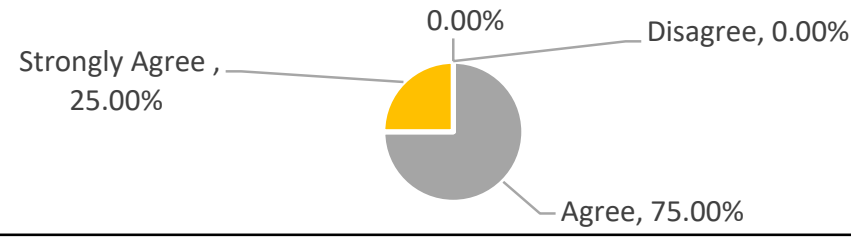

Figure 2. Pie Chart of Test Writers Responses to Statement Number 1

b) Figure 3 shows that $100 \%$ of the participants (i.e. All the 4 test writers) strongly agreed with statement 2 which states that 'I use the textbooks which are used in the teaching of English at [T] for writing my test items'. 
Statement 2: 'I use the textbooks which are used in the teaching of English at

[T] for writing my test items.'
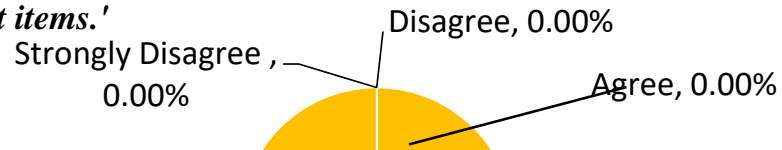

Strongly Agree, $100.00 \%$

Figure 3. Pie Chart of Test Writers Responses to Statement Number 2

c) Figure 4 illustrates that $50 \%$ of the test writers (i.e. TW1 and TW2) strongly agreed with statement number 3 which states that 'An English language test which is based on the learning objectives/outcomes of a teaching unit in a CEFR-linked/related textbook means that the test is CEFR-linked/related', while 50\% of the participants (i.e. TW 3 and TW4) agreed with the same statement.

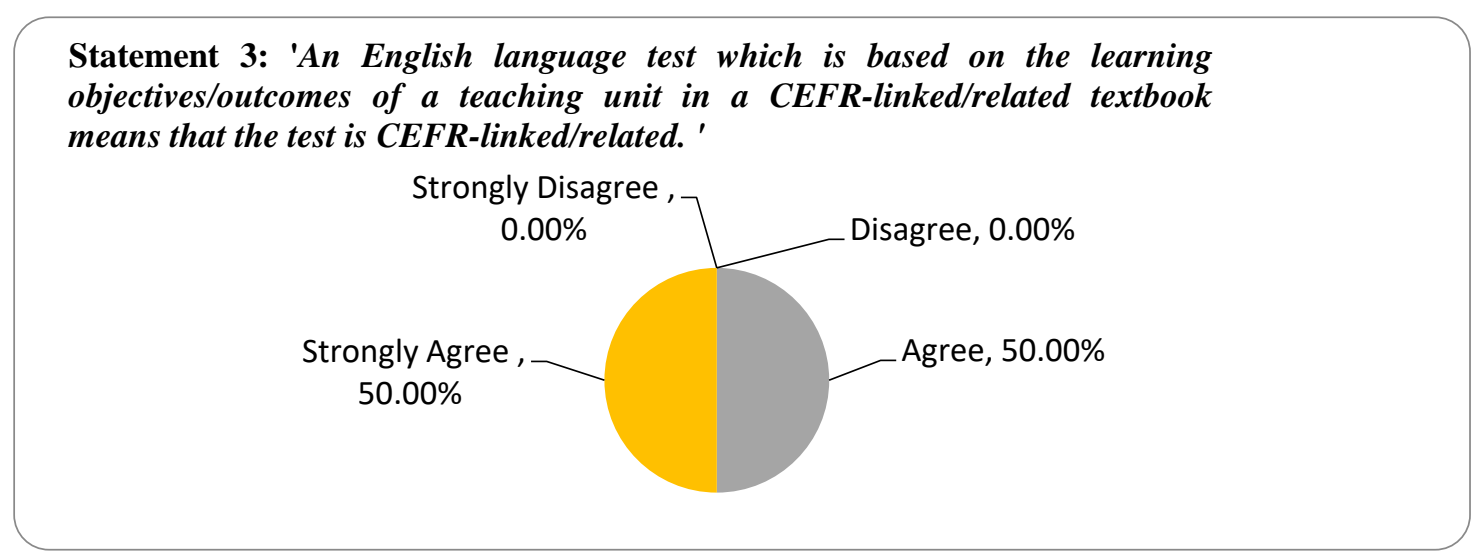

Figure 4. Pie Chart of Test Writers Responses to Statement Number 3

d) As demonstrated in Figure 5, 50\% of the participants (TW2 and TW4) strongly agreed with statement number 4 which states that ' $[T]$ requires that I write test items that are linked / related to the CEFR'. However, 50\% (TW1 and TW3) disagreed with the same statement. 
Statement 4: $[T]$ requires that I write test items that are linked/related to the CEFR.'

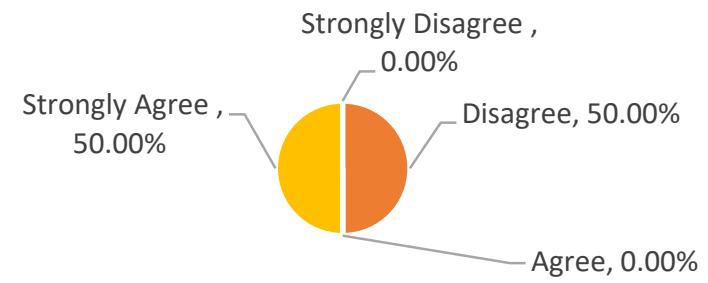

Figure 5. Pie Chart of Test Writers Responses to Statement Number 4

e) Figure 6 reflects that $50 \%$ of the participants (TW1 and TW3) disagreed with statement number 5 which states that 'When I write test items, I always refer to the CEFR'. TW2 (25\%) strongly agreed with the statement, whereas TW4 (25\%) agreed with the same statement.

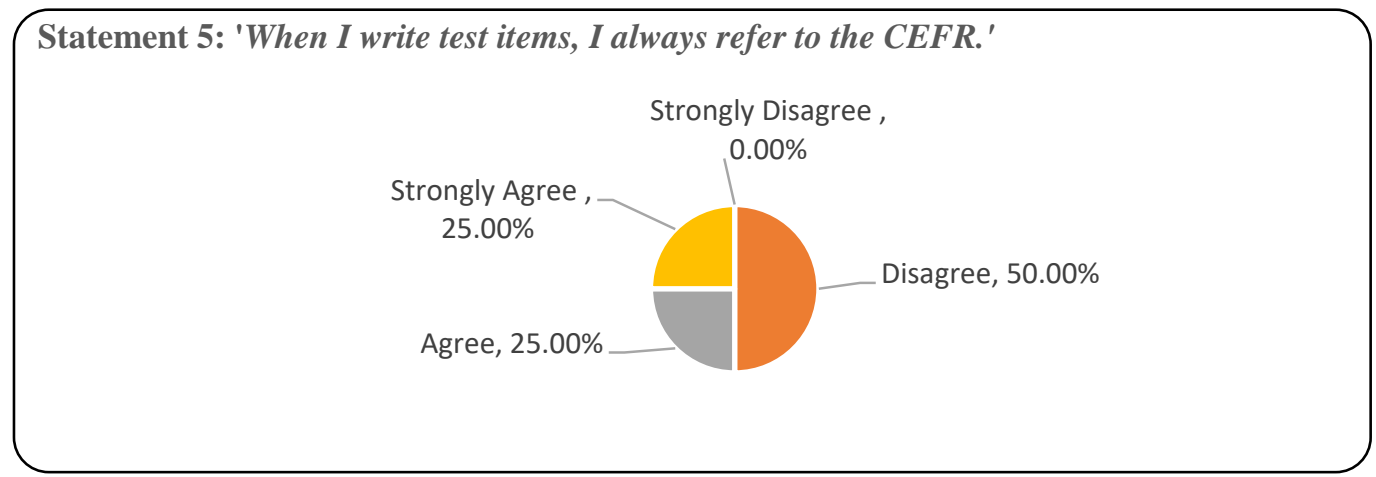

Figure 6. Pie Chart of Test Writers Responses to Statement Number 5

f) As shown in Figure 7, 50\% of the participants (TW2 and TW3) disagreed with statement number 6 which states that 'I have received training in using the Manual for Relating Language Examinations to the CEFR'. On the other hand, TW1 (25\%) strongly disagreed, whereas TW4 agreed with the same statement. 
Statement 6: 'I have received training in using the Manual for Relating Language Examinations to the CEFR.'

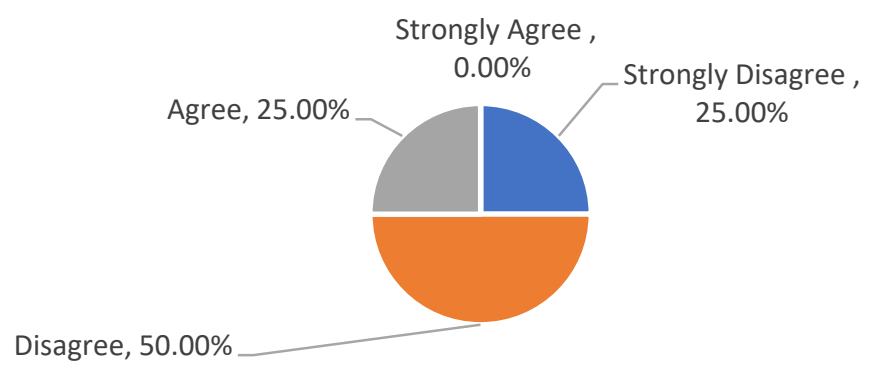

Figure 7. Pie Chart of Test Writers Responses to Statement Number 6

g) Figure 8 shows that $50 \%$ of the test writers (i.e. TW2 and TW4) strongly agreed with statement number 7 which states that 'I believe that there are some contextual barriers to using the Manual for Relating Language Examinations to the CEFR at [T]'. On the other hand, TW1 (25\% strongly agreed, whereas TW3 (25\%) disagreed with the same statement.

Statement 7: 'I believe that there are some contextual barriers to using the Manual for Relating Language Examinations to the CEFR at [T]'

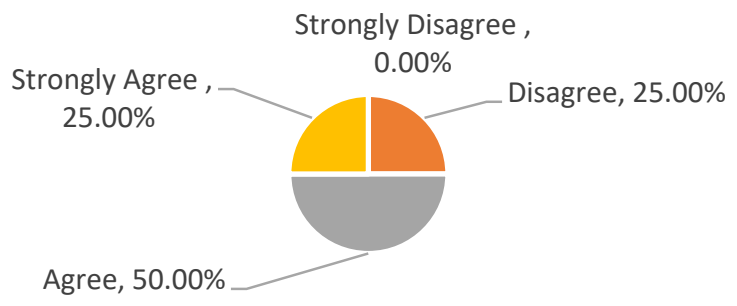

Figure 8. Pie Chart of Test Writers Responses to Statement Number 7

\subsection{Qualitative Findings}

As explained in the methodology section of this study, the semi-structured interviews are structured around the responses obtained in the survey questionnaire. Therefore, the semi-structured interviews stand as the main source of data collection for this study. Five broad themes emerged from the analysis of the one-to-one, semi-structured interviews held with the Test Writers.

5.3.1 Theme One: The Relevancy / link between the English Language Textbooks Used in Both the Teaching and Writing English Language Tests

The interview analysis indicates that the Test Writers seem to agree in their views that the 
English language textbooks which are used in the teaching and writing of the English language tests in the context of the current study are linked / related to the CEFR. However, all the participants reported that they did not independently verify whether the textbooks are CEFR linked / related. They relied on the publisher's word that the textbooks are CEFR related. For instance, according to TW1, the books are related to the CEFR because the publisher of the books states that they are linked or related to the CEFR. He adds "... we have to take a publisher's word". Similarly, when TW3 was asked why he agreed that the textbooks are linked/related to the CEFR, he said that "...our textbooks are aligned with the CEFR scale because "...it is shown on the cover".

5.3.2 Theme Two: CEFR Related English Language Textbooks and Writing Test Items in The Context of the Current Study

The participants, overall, demonstrated that they agree that they use the English language textbooks that are used in teaching to write the English language tests in the context of the current study. For example, TW1 views this issue from the perspective of achieving 'content validity' in writing English language tests. Similarly, TW2 believes that the English tests should be "...written in a way that mirror the way that the skills are taught in the book". Moreover, a common view amongst all the four Test Writers is that an English language test which is based on the learning objectives/outcomes of a textbook which its publisher claims that it is CEFR linked means that the test is CEFR-related. For instance, TW4 perceives that as long as the books are CEFR related, then the English tests which are based on these books are CEFR related "... because our tests are based on the books".

5.3.3 Theme Three: Relating the English Tests / Exams to the CEFR in the Context of the Current Study

The interview analysis suggests that the test writers have differing opinions about linking/relating the internally produced English tests to the CEFR in the context of this study. The analysis also shows that they have never made direct references to the CEFR document when writing their test items. This is because according to them, as long as the English tests are based on the learning outcomes of a textbook which the publisher claims that it is CEFR-related then the English tests will be CEFR-linked as well. The interview analysis also revealed that the participants have not received formal directions to indicate that that have to link the English tests to the CEFR. For instance, when TW3 was asked whether [T] requires that he writes test items which are CEFR linked/related, he reported that "...the English language center has never required that I write items that are linked to the CEFR. It has always required that I write items that are linked to the textbooks".

5.3.4 Theme Four: Test Writers' Familiarity with and Usage of the Manual for Relating Language Examinations to the CEFR 
The interview analysis revealed a number of issues related to the participants' familiarity with and usage of the Manual for Relating Language Examinations to the CEFR. Firstly, the test writers vary in the ways they became familiar with the Manual for Relating Language Examinations to the CEFR. Most of these ways are done through the personal efforts of the test writers. Secondly, the test writers have not received any formal training in using the Manual. In addition, they do not refer to the Manual to make sure that their exams are related to the CEFR. However, they all indicated that they need training in using the Manual because they believe it will help them make sure that their exams are closely linked to the CEFR.

\subsubsection{Theme Five: The Contextual Barriers to Using the Manual for Relating Language} Examinations to the CEFR

The interview analysis led to a number of issues related to the contextual barriers to using the Manual for Relating Language Examinations to the CEFR. For instance, one participant (i.e. TW1) perceives that there are differences between the context for which the CEFR is originally designed i.e. European countries and the context addressed in this study i.e. Middle Eastern Arab Country. He noted that this concern is particularly relevant to the differences between European languages and the Arabic language. For example, the writing system is from left to right, full stops, capital letters, full stops commas, inverted commas, etc. Therefore, a suggestion is made to develop a framework for learning, teaching, and assessing the English language in Saudi Arabia and in the Middle East as a whole.

Other participants (e.g. TW2 and TW4) expressed their concerns regarding the workload, time, and stress. Nonetheless, one participant (i.e. TW3) perceived that there are no contextual barriers to using the Manual as "management is open to any kind of training". However, he added that the institution must make it clear that it is a requirement to align the English exams to the CEFR. Similarly, TW4 perceived that there might be some cultural barriers to using the Manual and the CEFR in the context addressed in this paper. Finally, the research participants agreed on their views that the institution has to provide a formal training on using the Manual and the CEFR.

\section{Discussion}

The above analysis indicates a number of important findings. Firstly, all the research participants seem to have a consensus that the textbooks which are used in teaching English at the institution in which this study is conducted are CEFR linked / related. However, what is interesting about this finding is that none of the test writers conducted research to verify whether the textbooks are CEFR linked / related. All the participants reported that they relied on the publisher's word that the book is CEFR-linked. This raises the question whether there is any empirical evidence (apart from the publisher's word on the book cover) that these textbooks are CEFR related / linked. According to related literature, there is a manual for relating language examinations to the CEFR (Council of Europe, 2009), however nothing is found in the literature to indicate that there is a manual for relating English language 
textbooks to the CEFR. Secondly, all the test writers seem to have an agreement that an English language test which is based on the learning objectives/outcomes of a teaching unit in a CEFR-linked/related textbook implies that the test is CEFR-linked/related. This view might be related to the test writers' perception that the books are CEFR linked, therefore they view that a language test that is based on the outcomes of these books will then be CEFR linked /related. Thirdly, there is disagreement among the test writers on whether the institution requires them to write exams that are related to the CEFR. This is a significant finding as the institution addressed in this study perceives that its exams and course outcomes are related / linked to the CEFR, however the research participants seemed to disagree that the institution requires them to write tests that are CEFR related. Fourthly, the results show that there is a disagreement among the test writer participants on whether they refer to the CEFR when they write their exams. This raises the following question: How do the test writers verify that their exams are CEFR linked? Fifthly, most of the test writers disagreed that they have received training in using the Manual for Relating Language Examinations to the CEFR. This is also an important finding. As indicated in the literature review section, the Manual is produced by the Council of Europe (2009) and it specifies the stages of linking/relating language examinations to the CEFR. The Council of Europe argues that the Manual "provides a guide specifically focused on procedures involved in the justification of a claim that a certain examination or test is linked to the CEFR" (Council of Europe, 2009, p.1).

Since, the Test Writers have not received training in using the Manual then how do they verify whether the exams which they develop are related / linked to the CEFR? Finally, the majority of the test writers agreed that there are some contextual barriers (i.e. linguistic, logistical \& cultural) to using the Manual and the CEFR in the context wherein this study is conducted. This is a significant finding as it calls for further research to explore these contextual barriers.

\section{Implications and Recommendations}

The test writers in the context of this study view that the English language exams which they develop are CEFR linked/related because they are based on the learning outcomes of textbooks which, according to the publisher, are CEFR linked / related. Therefore, ELT publishing companies need to provide English language teaching institutions with an empirical research evidence that validates that their ELT materials are CEFR related. In addition, the institution addressed in this study needs to provided its internal test writers staff with training on the Manual for Relating Language Examinations to the CEFR in order to enable them to write and develop tests that are CEFR related/linked. Moreover, the institution under discussion may formally and explicitly inform and require its internal test writers to ensure that the internal English tests which they produce are linked/related to the CEFR. Finally, the contextual barriers related to the application of the Manual and the CEFR in a context that is different from the European context are to be considered. 


\section{Suggestions for Future Studies}

Further research is needed to explore the contextual barriers related to the implementation of the CEFR and the Manual for Relating Language Examinations in a context (i.e. a Middle Eastern Arab Country) that is different from the one for which it is originally designed (i.e. the Council of European Member States). In addition, further research is needed to address the following question: Would a test that is based on the learning outcomes of a textbook, which its publisher claims that it is linked / related to the CEFR, make the test CEFR linked/related?

\section{Conclusion}

This study was undertaken with the aim to investigate whether the internal English language tests at a Saudi Arabian university are linked / related to the CEFR. It explored the views of the test writers who are responsible for producing the internal English exams in the context addressed in this study. The study showed that the target participants perceive that the English language textbooks which are used in the teaching and writing of the English language tests in the context of the current study are CEFR-linked because they relied on publisher's word on the book cover which states that the textbooks are linked / related to the CEFR. Therefore, according to them, the English tests which they write are CEFR related because they are based on the learning outcomes of a textbook which its publisher claims it is CEFR-linked. Nonetheless, the current study found that that no effort has been done to verify that these books are CEFR-linked. Moreover, this study found that the institution needs to formally and explicitly requires its test writers to align the English tests to the CEFR. Furthermore, the test writers need to receive proper training on both the Manual and the CEFR. Finally, the contextual barriers to the implementation of the CEFR and the Manual for Relating Language Examinations to the CEFR in a Middle Eastern Arab country need to be considered.

\section{Acknowledgement}

This research study is financed by the researchers. We would like to thank all the individuals who participated in this research study. We are also thankful to both the English language Center of Taibah University, KSA and the University of KwaZulu-Natal, South Africa.

\section{References}

Alderson, J. C. (Ed.). (2002). Common European Framework of Reference for Languages: Learning, teaching, assessment: Case studies. Strasbourg: Council of Europe.

Alderson, J. C. (2006). [EALTA-discussion] CEFR. Message posted to LTEST-L, 'Language Testing Research and Practice'. Retrieved from: http://lists.su.edu/archives/ltest-1.html

Alderson, J. C. (2007). Linkage to the CEFR. Message posted to LTESTL, 'Language Testing 
Research and Practice'. Retrieved from: http://lists.su.edu/archives/ltest-1.html

Alderson, J. C. (2007). CEFR - thread one (SLA). Message posted to LTEST-L, 'Language Testing Research and Practice'. Retrieved from: http://lists.su.edu/archives/ltest-1.html

Byram, M., \& Parmenter, L. (2012). The Common European Framework of Reference: The globalisation of language education policy. Bristol: Multilingual Matters.

Coste, D (2007). Contextualising uses of the Common European Framework of Reference for Languages. Paper presented at the Council of Europe Policy Forum on the Use of the CEFR, Strasbourg. Retrieved from:

https://rm.coe.int/contextualising-uses-of-the-common-european-framework-of-reference-for/ $16805 \mathrm{ab} 765$

Council of Europe. (2018). Common European Framework of Reference for Languages: Learning, Teaching, Assessment. Companion Volume with New Descriptors, Council of Europe. Retrieved from:

https://rm.coe.int/cefr-companion-volume-with-new-descriptors-2018/1680787989

Council of Europe. (1954). European cultural convention.

Retrieved from: http://conventions.coe.int/Treaty/en/Treaties/Html/018.htm

Council of Europe. (2003). Relating language examinations to the Common European Framework of Reference for Languages: Learning, teaching, assessment (CEF) [Preliminary pilot version of the Manual]. Strasbourg, France: Council of Europe. Retrieved from:

http://mestreacasa.gva.es/c/document_library/get_file?folderId=500005182952\&name=DLF E-455084.pdf

Council of Europe. (2004). Reference supplement to the preliminary pilot version of the Manual for relating language examinations to the Common European Framework of Reference for Languages: Learning, teaching, assessment. Strasbourg, France: Council of Europe, Language Policy Division.

Council of Europe. (2009a). Relating language examinations to the Common European Framework of Reference for Languages: Learning, teaching, assessment (CEFR): A manual. Strasbourg, France: Council of Europe, Language Policy Division. Retrieved from: https://rm.coe.int/CoERMPublicCommonSearchServices/DisplayDCTMContent?documentId $=0900001680667 \mathrm{a} 2 \mathrm{~d}$

Council of Europe. (2009b). Reference supplement to the manual for relating language examinations to the Common European Framework of Reference for Languages: Learning, teaching, assessment (CEFR). Strasbourg, France: Council of Europe, Language Policy Division.

Figueras, N. (2013). The impact of the CEFR. ELT Journal, 66(4), 477-485. Retrieved from: https://www.academia.edu/38964197/The_impact_of_the_CEFR?auto=download 


\section{Mll Macrothink}

Knatarcioglu, E., \& Papageorgiou, S. (2012). The Common European Framework of Reference. In C. Coombe, P. Davidson, B. O'Sullivan, \& and S. Stoynoff, (Eds.), The Cambridge Guide to Second Language Assessment ( $1^{\text {st }}$ ed. pp. 82-88). New York: Cambridge University Press.

McBeath, N. (2011). The Common European Framework of Reference for Language; learning, teaching, assessment. Arab World English Journal, 2(1), 186-213. Retrieved from: https://www.awej.org/images/AllIssues/Volume2/Volume2Number1Jan2011/7.pdf

McNamara, T. (2000). Language testing. Oxford University Press

McNamara, T. (2007). Linkage to the CEFR. Message posted to LTESTL, 'Language Testing Research and Practice'. Retrieved from http://lists.su.edu/archives/ltest-1.html

McNamara, T. (2007a). Linkage to the CEFR. Message posted to LTESTL, 'Language Testing Research and Practice'. Retrieved from: http://lists.su.edu/archives/ltest-l.html

McNamara, T. (2007b). CEFR - thread one (SLA). Message posted to LTEST-L, 'Language Testing Research and Practice'. Retrieved from: http://lists.su.edu/archives/ltest-1.html

McNamara, T. (2007c). The CEFR and beyond. PowerPoint document presented at the Fourth Annual Conference of EALTA: The CEFR in Europe and beyond: Challenges and experiences, Sitges, Spain. Retrieved from:

http://www.ealta.eu.org/conference/2007/docs/pres_sunday/McNamara\%20Discussant.pdf

McNamara, T. (2006). [EALTA-discussion] CEFR. Message posted to LTEST-L, 'Language Testing Research and Practice'. Retrieved from http://lists.su.edu/archives/ltest-l.html

Martyniuk, W., \& Noijons, J. (2007). Executive summary of results of a survey on the use of the CEFR at national level in the Council of Europe member states. Retrieved from: www.coe.int/t/dg4/linguistic/Source/Survey_CEFR_2007_EN.doc

Nagai, N., \& O' Dwyer, F. (2011). The actual and potential impacts of the CEFR on language education in Japan. Synergies Europe, 6, 141-152.

Taylor, L., \& Jones, N. (2006). Cambridge ESOL exams and the Common European Framework. Cambridge ESOL Research Notes, May 2006(24), 2-5. Retrieved from: http://www.cambridgeesol.org/rs_notes/rs_nts2024.pdf

Wahyuni, D. (2012). The Research Design Maze: Understanding Paradigms, Cases, Methods and Methodologies. Journal of Applied Management Accounting Research, 10(1), 69-80.

Retrieved

from: https://www.researchgate.net/publication/256024036_The_Research_Design_Maze_Understa nding_Paradigms_Cases_Methods_and_Methodologies

Weir, C. (2005). Limitations of the Common European Framework for developing comparable examinations and tests. Language Testing, 22(3), 282-300. 
Appendices

\section{Appendix A}

\section{QUESTIONNAIRE}

Please read the following statements and check $(\sqrt{ })$ the option which corresponds to your opinion.

Test Writers' Perceptions of the English Language Tests in Relation to the Common European Framework of Reference (CEFR) at a Public Saudi Arabian University

\begin{tabular}{|c|c|c|c|c|c|}
\hline & Questions & $\begin{array}{l}\text { Strongly } \\
\text { Disagree }\end{array}$ & Disagree & Agree & $\begin{array}{l}\text { Strongly } \\
\text { Agree }\end{array}$ \\
\hline $\mathbf{1 .}$ & $\begin{array}{l}\text { The textbooks which are used in the teaching of English } \\
\text { at the university are linked/related to the CEFR*. }\end{array}$ & & & & \\
\hline 2. & $\begin{array}{l}\text { I use the textbooks which are used in the teaching of } \\
\text { English the university for writing my test items. }\end{array}$ & & & & \\
\hline 3. & $\begin{array}{l}\text { An English language test which is based on the } \\
\text { learning objectives/outcomes of a teaching unit in a } \\
\text { CEFR-linked/related textbook means that the test is } \\
\text { CEFR-linked/related. }\end{array}$ & & & & \\
\hline 4. & $\begin{array}{l}\text { The university requires that I write test items that are } \\
\text { linked/related to the CEFR. }\end{array}$ & & & & \\
\hline 5. & When I write test items, I always refer to the CEFR. & & & & \\
\hline 6. & $\begin{array}{l}\text { I have received training in using the Manual for } \\
\text { Relating Language Examinations to the CEFR. }\end{array}$ & & & & \\
\hline 7. & $\begin{array}{l}\text { I believe that there are some contextual barriers to } \\
\text { using the Manual for Relating Language Examinations } \\
\text { to the CEFR at the English Language Center of } \\
\text { University }\end{array}$ & & & & \\
\hline
\end{tabular}

* CEFR= Common European Framework of Reference (CEFR): Learning, teaching, assessment 


\section{Appendix B: \\ Interview Questions for Test Writer 1 (TW1)}

Statement:

Firstly, I would like to thank you for participating in both the questionnaire and interview of this study. As stated in the questionnaire that you completed earlier, I am interested in learning about whether the English language tests which are produced by the English Language Center of Taibah University are linked / related to the Common European Framework of Reference (CEFR).

In this regard, I would like to stress that:

- Your confidentiality is guaranteed as your inputs will not be attributed to you in person, but reported only as a population member opinion.

- Any information given by you cannot be used against you, and the collected data will be used for purposes of this research only.

- Data will be stored in secure storage and destroyed after 5 years.

- Your involvement is purely for academic purposes only, and there are no financial benefits involved.

\begin{tabular}{|c|c|c|}
\hline & TW1: & Code: Test Writer 1 (TW1) \\
\hline & Topics & Questions for Each Topic \& Specific issue related to the topic \\
\hline 1. & $\begin{array}{l}\text { English Language } \\
\text { Textbooks \& CEFR }\end{array}$ & $\begin{array}{l}\text { In your response to statement number } 1 \text { on the survey, you indicated } \\
\text { that you agree that "The textbooks which are used in the teaching of } \\
\text { English at the English Language Center of Taibah University are } \\
\text { linked/related to the CEFR." } \\
\text { 1. Could you please explain why did you agree with this } \\
\text { statement? } \\
\text { 2. Could you please explain why you didn't choose strongly } \\
\text { agree? } \\
\text { 3. How do you make sure that the textbooks are linked/related to } \\
\text { the CEFR? }\end{array}$ \\
\hline 2. & $\begin{array}{l}\text { CEFR-linked/related } \\
\text { English language } \\
\text { textbooks\& test } \\
\text { items }\end{array}$ & $\begin{array}{l}\text { In your response to statement number } 2 \text { you strongly agreed that you } \\
\text { use the textbooks which are used in the teaching of English at the } \\
\text { English Language Center of Taibah University for writing my test } \\
\text { items. } \\
\text { 1. Could you please explain why do you have to use these } \\
\text { textbooks for writing your test items? }\end{array}$ \\
\hline
\end{tabular}




\section{Ml Macrothink}

\begin{tabular}{|c|c|c|}
\hline & & $\begin{array}{l}\text { In your response to statement number } 3 \text { on the survey, you strongly } \\
\text { agreed that "An English language test which is based on the learning } \\
\text { objectives/outcomes of a teaching unit in a CEFR-linked/related } \\
\text { textbook means that the test is CEFR-linked/related." } \\
\text { 1. Could you please explain why did you strongly agree with } \\
\text { this statement? }\end{array}$ \\
\hline \multirow[t]{2}{*}{3.} & $\begin{array}{l}\text { Linking/relating test } \\
\text { items \& Exams to } \\
\text { the CEFR }\end{array}$ & $\begin{array}{l}\text { You disagreed with statement number } 4 \text { which states that your } \\
\text { institution requires that you write test items that are linked/related to } \\
\text { the CEFR" } \\
\quad \text { 1. Why did you disagree with this statement? }\end{array}$ \\
\hline & & $\begin{array}{l}\text { You disagreed with statement number } 5 \text { which states that "When you } \\
\text { write test items, you always refer to the CEFR." } \\
\text { 1. Why did you disagree with this statement? }\end{array}$ \\
\hline 4. & $\begin{array}{l}\text { Test Writer's Usage } \\
\& \text { Familiarity with } \\
\text { the Manual for } \\
\text { Relating Language } \\
\text { Examinations to the } \\
\text { CEFR. }\end{array}$ & $\begin{array}{l}\text { In your response to statement number } 6 \text { on the survey you strongly } \\
\text { disagreed that you have received training in using the Manual for } \\
\text { Relating Language Examinations to the CEFR. However, your } \\
\text { response to the survey shows that you have been a test writer for } 9 \\
\text { years, } \\
\text { 1. So, why do you think you haven't yet received training in using } \\
\text { the Manual for Relating Language Examinations to the CEFR } \\
\text { so far? }\end{array}$ \\
\hline 5. & $\begin{array}{l}\text { Contextual Barriers } \\
\text { to Using the Manual } \\
\text { for Relating } \\
\text { Language } \\
\text { Examinations to the } \\
\text { CEFR at the English } \\
\text { Language Center of } \\
\text { Taibah University }\end{array}$ & $\begin{array}{l}\text { You strongly agreed with statement number } 7 \text { on the survey which } \\
\text { states that "there are some contextual barriers to using the Manual for } \\
\text { Relating Language Examinations to the CEFR at the English } \\
\text { Language Center of Taibah University." } \\
\text { 1. Why do you believe so? } \\
\text { 2. What are some of these contextual barriers? }\end{array}$ \\
\hline
\end{tabular}

Concluding statement:

OK. Thank you TW1 for participating in this interview and for letting me record this interview. 


\section{Appendix C: \\ Interview Questions for Test Writer 2 (TW2)}

Statement:

Firstly, I would like to thank you for participating in both the questionnaire and interview of this study. As stated in the questionnaire that you completed earlier, I am interested in learning about whether the English language tests which are produced by the English Language Center of Taibah University are linked / related to the Common European Framework of Reference (CEFR).

In this regard, I would like to stress that:

- Your confidentiality is guaranteed as your inputs will not be attributed to you in person, but reported only as a population member opinion.

- Any information given by you cannot be used against you, and the collected data will be used for purposes of this research only.

- Data will be stored in secure storage and destroyed after 5 years.

- Your participation is purely for academic purposes only, and there are no financial benefits involved.

Test Writers

\begin{tabular}{|c|c|c|}
\hline & TW2 & Code: TW2 \\
\hline & Topics & Questions for Each Topic \& Specific Issue Related to the Topic \\
\hline 1 & $\begin{array}{l}\text { English Language } \\
\text { Textbooks \& CEFR }\end{array}$ & $\begin{array}{l}\text { In your response to statement number } 1 \text { on the survey, you indicated } \\
\text { that you strongly agree that "The textbooks which are used in the } \\
\text { teaching of English at the English Language Center of Taibah } \\
\text { University are linked/related to the CEFR." } \\
\text { 1. Could you please explain why did you strongly agree with this } \\
\text { statement? } \\
\text { 2. How do you make sure that the textbooks are linked/related to } \\
\text { the CEFR? }\end{array}$ \\
\hline \multirow[t]{2}{*}{2} & \multirow[t]{2}{*}{$\begin{array}{l}\text { CEFR-linked/related } \\
\text { English language } \\
\text { textbooks\& test } \\
\text { items }\end{array}$} & $\begin{array}{l}\text { In your response to statement number } 2 \text { you strongly agreed that you } \\
\text { use the textbooks which are used in the teaching of English at the } \\
\text { English Language Center of Taibah University for writing my test } \\
\text { items. } \\
\text { 1. Could you please explain why do you have to use these } \\
\text { textbooks for writing your test items? }\end{array}$ \\
\hline & & $\begin{array}{l}\text { In your response to statement number } 3 \text { on the survey, you indicated } \\
\text { that you strongly agree that "An English language test which is based } \\
\text { on the learning objectives/outcomes of a teaching unit in a } \\
\text { CEFR-linked/related textbook means that the test is } \\
\text { CEFR-linked/related." }\end{array}$ \\
\hline
\end{tabular}




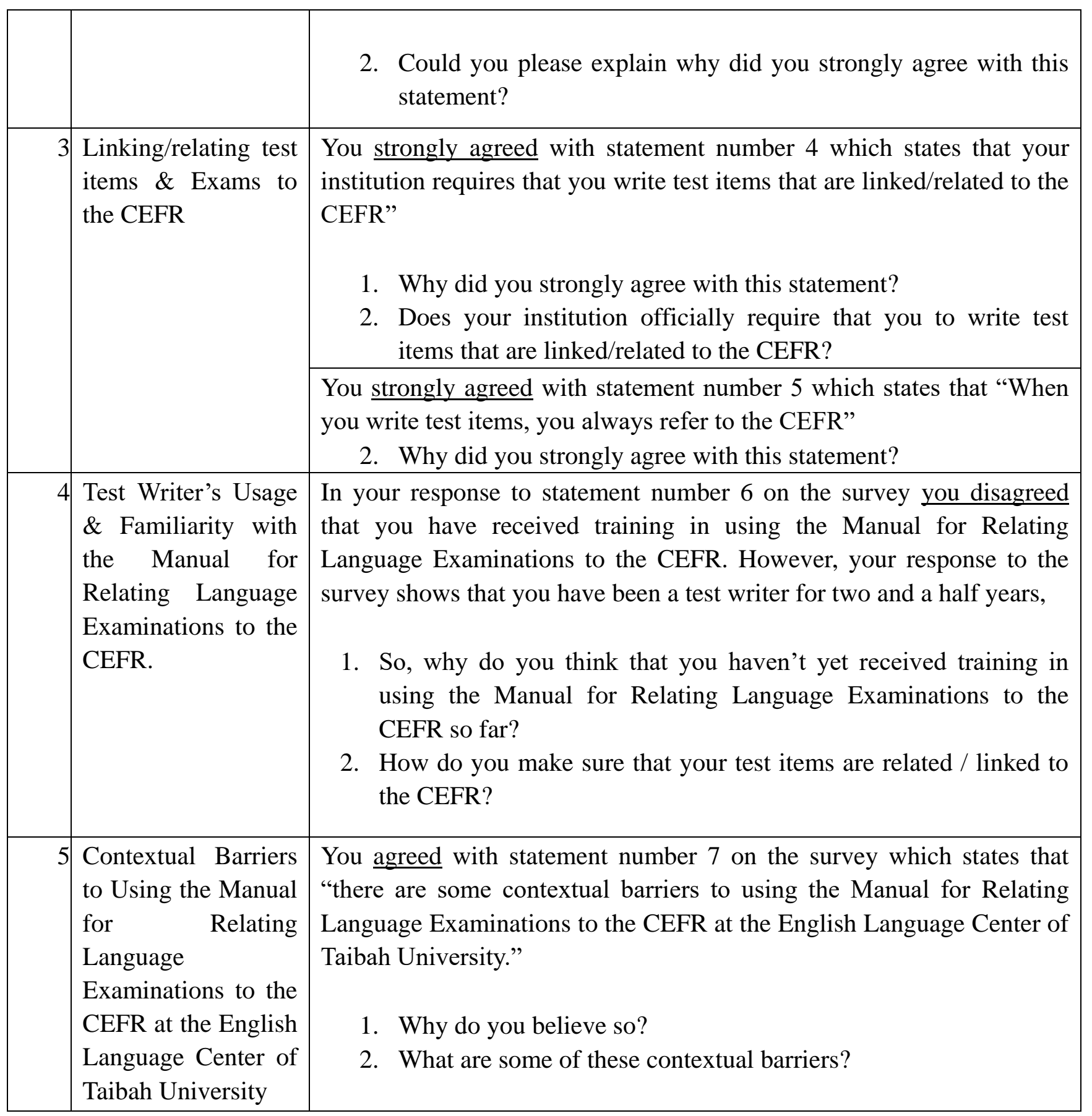

Concluding statement:

OK. Thank you Mr. TW2 for participating in this interview and for letting me record this interview. 


\section{Appendix D: \\ Interview Questions for Test Writer 3 (TW3)}

Statement:

Firstly, I would like to thank you for participating in both the questionnaire and interview of this study. As stated in the questionnaire that you completed earlier, I am interested in learning about whether the English language tests which are produced by the English Language Center of Taibah University are linked / related to the Common European Framework of Reference (CEFR).

In this regard, I would like to stress that:

- Your confidentiality is guaranteed as your inputs will not be attributed to you in person, but reported only as a population member opinion.

- Any information given by you cannot be used against you, and the collected data will be used for purposes of this research only.

- Data will be stored in secure storage and destroyed after 5 years.

- Your participation is purely for academic purposes only, and there are no financial benefits involved.

\begin{tabular}{|c|c|c|}
\hline & TW3 & Code: TW3 \\
\hline & Topics & Questions for Each Topic \& Specific Issue Related to The Topic \\
\hline \multirow[t]{4}{*}{1.} & $\begin{array}{l}\text { English Language } \\
\text { Textbooks \& CEFR }\end{array}$ & $\begin{array}{l}\text { In your response to statement number } 1 \text { on the survey, you agreed } \\
\text { that "The textbooks which are used in the teaching of English at the } \\
\text { English Language Center of Taibah University are linked/related to } \\
\text { the CEFR." }\end{array}$ \\
\hline & & $\begin{array}{l}\text { 1. Could you please explain why did you agree with this } \\
\text { statement? } \\
\text { 2. Could you please explain why you didn't choose strongly } \\
\text { agree? } \\
\text { 3. How do you make sure that the textbooks are linked/related } \\
\text { to the CEFR? }\end{array}$ \\
\hline & & $\begin{array}{l}\text { In your response to statement number } 2 \text { you strongly agreed that you } \\
\text { use the textbooks which are used in the teaching of English at the } \\
\text { English Language Center of Taibah University for writing my test } \\
\text { items. }\end{array}$ \\
\hline & & $\begin{array}{l}\text { 1. Could you please explain why do you have to use these } \\
\text { textbooks for writing your test items? }\end{array}$ \\
\hline
\end{tabular}




\section{Macrothink}

2. CEFR-linked/related English language textbooks\& test items
In your response to statement number 3 on the survey, you agreed that "An English language test which is based on the learning objectives/outcomes of a teaching unit in a CEFR-linked/related textbook means that the test is CEFR-linked/related."

1. Could you please explain why did you strongly agree with this statement?

3. Linking/relating test items \& Exams to the CEFR

You disagreed with statement number 4 which states that your institution requires that you write test items that are linked/related to the CEFR"

1. Could you please explain why did you disagree with this statement?

You disagreed with statement number 5 which states that "When you write test items, you always refer to the CEFR"

1. Why did you disagree with this statement?

4. Test Writer's Usage In your response to statement number 6 on the survey you disagreed \& Familiarity with the Manual for Relating Language Examinations to the CEFR.

5. Contextual Barriers to Using the Manual for Relating Language

Examinations to the CEFR at the English Language Center of Taibah University that you have received training in using the Manual for Relating Language Examinations to the CEFR. However, your response to the survey shows that you have been a test writer for 6 years.

1. So, why do you think that you haven't yet received training in using the Manual for Relating Language Examinations to the CEFR so far?

You disagreed with statement number 7 on the survey which states that "there are some contextual barriers to using the Manual for Relating Language Examinations to the CEFR at the English Language Center of Taibah University."

1. Could you please explain? (learners, teachers, management, culture, etc.).

Concluding statement:

OK. Thank you Mr. TW3 for participating in this interview and for letting me record this interview. 


\section{Appendix E: \\ Interview Questions for Test Writer 4 (TW4)}

Statement:

Firstly, I would like to thank you for participating in both the questionnaire and interview of this study. As stated in the questionnaire that you completed earlier, I am interested in learning about whether the English language tests which are produced by the English Language Center of Taibah University are linked / related to the Common European Framework of Reference (CEFR).

In this regard, I would like to stress that:

- Your confidentiality is guaranteed as your inputs will not be attributed to you in person, but reported only as a population member opinion.

- Any information given by you cannot be used against you, and the collected data will be used for purposes of this research only.

- Data will be stored in secure storage and destroyed after 5 years.

- Your participation is purely for academic purposes only, and there are no financial benefits involved.

\begin{tabular}{|c|c|c|}
\hline & TW4 & Code: Test Writer 4 \\
\hline & Topics & Questions for Each Topic \& Specific Issue Related to The Topic \\
\hline \multirow[t]{2}{*}{1} & $\begin{array}{l}\text { English Language } \\
\text { Textbooks \& CEFR }\end{array}$ & $\begin{array}{l}\text { In your response to statement number } 1 \text { on the survey, you agreed } \\
\text { that "The textbooks which are used in the teaching of English at the } \\
\text { English Language Center of Taibah University are linked/related to } \\
\text { the CEFR." } \\
\text { 1. Could you please explain why did you agree with this } \\
\text { statement? } \\
\text { 2. Could you please explain why you didn't choose strongly } \\
\text { agree? } \\
\text { 3. How do you make sure that the textbooks are linked/related to } \\
\text { the CEFR? }\end{array}$ \\
\hline & & $\begin{array}{l}\text { In your response to statement number } 2 \text { you strongly agreed that you } \\
\text { use the textbooks which are used in the teaching of English at the } \\
\text { English Language Center of Taibah University for writing my test } \\
\text { items. } \\
\text { 1. Could you please explain why do you have to use these } \\
\text { textbooks for writing your test items? }\end{array}$ \\
\hline 2. & $\begin{array}{l}\text { CEFR-linked/relate } \\
\text { d English language } \\
\text { textbooks\& test } \\
\text { items }\end{array}$ & $\begin{array}{l}\text { In your response to statement number } 3 \text { on the survey, you indicated } \\
\text { that you agree that "An English language test which is based on the } \\
\text { learning objectives/outcomes of a teaching unit in a }\end{array}$ \\
\hline
\end{tabular}




\begin{tabular}{|c|c|c|}
\hline & & $\begin{array}{l}\text { CEFR-linked/related textbook means that the test is } \\
\text { CEFR-linked/related." } \\
\text { 1. Could you please explain why do you believe so? } \\
\text { 2. Could you please explain why you didn't choose strongly } \\
\text { agree? }\end{array}$ \\
\hline 3. & $\begin{array}{l}\text { Linking/relating } \\
\text { test items \& Exams } \\
\text { to the CEFR }\end{array}$ & $\begin{array}{l}\text { You strongly agreed with statement number } 4 \text { which states that your } \\
\text { institution requires that you write test items that are linked/related to } \\
\text { the CEFR" } \\
\text { 1. Why did you strongly agree with this statement? } \\
\text { 2. Does your institution officially require that you to write test } \\
\text { items that are linked/related to the CEFR? (optional) }\end{array}$ \\
\hline 4. & $\begin{array}{l}\text { Test Writer's Usage } \\
\& \text { Familiarity with } \\
\text { the Manual for } \\
\text { Relating Language } \\
\text { Examinations to the } \\
\text { CEFR. }\end{array}$ & $\begin{array}{l}\text { In your response to statement number } 6 \text { on the survey you agreed that } \\
\text { you have received training in using the Manual for Relating } \\
\text { Language Examinations to the CEFR. } \\
\text { 1. Could you please explain how did you get this training / } \\
\text { orientation? } \\
\text { 2. Was it a formal training/orientation? } \\
\text { 3. Was it for test writing purposes? }\end{array}$ \\
\hline 5 & $\begin{array}{l}\text { Contextual Barriers } \\
\text { to Using the } \\
\text { Manual for } \\
\text { Relating Language } \\
\text { Examinations to the } \\
\text { CEFR at the } \\
\text { English Language } \\
\text { Center of Taibah } \\
\text { University }\end{array}$ & $\begin{array}{l}\text { You agreed with statement number } 7 \text { on the survey which states that } \\
\text { "there are some contextual barriers to using the Manual for Relating } \\
\text { Language Examinations to the CEFR at the English Language Center } \\
\text { of Taibah University." } \\
\text { 1. Why do you believe so? } \\
\text { 2. What are some of these contextual barriers (in terms of the } \\
\text { learners, teachers, management, etc.)? }\end{array}$ \\
\hline
\end{tabular}

\section{Concluding statement:}

OK. Thank you Mr. TW4 for participating in this interview and for letting me record this interview. 


\section{Copyright Disclaimer}

Copyright for this article is retained by the author(s), with first publication rights granted to the journal.

This is an open-access article distributed under the terms and conditions of the Creative Commons Attribution license (http://creativecommons.org/licenses/by/3.0/). 